\title{
Deconstructing Media Framing of the Waco Siege and Standoff on
} the $25^{\text {th }}$ Anniversary

\author{
Stuart A. Wright ${ }^{1}$
}

[Article copies available for a fee from The Transformative Studies Institute. E-mail address: journal@transformativestudies.org Website: http://www.transformativestudies.org (C2020 by The Transformative Studies Institute. All rights reserved.]

Book Review Editor's Note: While this space is primarily devoted to the scholarly analysis of books, every so often, I come across thoughtful and evocative pieces which examine other forms of media, such as film. In the essay below, Dr. Stuart A. Wright, critically analyzes seven documentaries related to the Federal Siege of the Branch Davidians. An alternate version of this evocative review essay was published in Nova Religio (Feb2019, Vol. 22 Issue 3, p. 108-120) and permission was granted by the University of California Press to publish the following version in Theory in Action.

Secrets of Waco. CBS 48 Hours, Season 31, Episode 35. Written by Nancy Kramer. Directed by Rob Klug. Premier date December 29, 2017.

Truth and Lies: Waco. ABC 20/20. Written by Muriel Pearson. Premier date April 1, 2018.

Days That Shaped America: The Waco Siege. The History Channel. Season 1, Episode 2. Premier date April 15, 2018.

\footnotetext{
${ }^{1}$ Stuart A. Wright, Ph.D., is Professor of Sociology and Chair of the Department of Sociology, Social Work and Criminal Justice at Lamar University. Dr. Wright is known internationally for his research on religious and political movements, conflict and violence. He has published six books, including Armageddon in Waco (1995), Patriots, Politics, and the Oklahoma City Bombing (2007), Saints under Siege: The Texas State Raid on the Fundamentalist Latter Day Saints (with James T. Richardson, 2011), and Storming Zion (with Susan J. Palmer, 2015). Address correspondence to: Stuart A. Wright, e-mail: wrightsa@lamar.edu.
} 
Waco: The Longest Siege. Smithsonian Channel. Premier date April 9, 2018.

Waco: How It Really Happened with Hill Harper. HLN 2 hours. Premier date April 22, 2018.

Waco: Madman or Messiah? A\&E. Two Episodes. Written and directed by Christopher Spencer. RAW TV Limited. 90 minutes. Premier dates January 28-29, 2018.

Waco. Paramount Network. Six-episode miniseries. Created by Drew Dowdle and John Erick Dowdle. Premier date January 24, 2018.

Twenty-five years after the disastrous federal siege and standoff targeting the Branch Davidian sect near Waco, Texas in 1993 we are witnessing a wave of television documentaries and renewed media coverage of the historic conflict. 2018 marks the twenty-fifth anniversary of what has been called one of the worst federal law enforcement disasters in American history. This paper examines six Waco documentaries and a docudrama that premiered in 2018 on major television networks, all alleging to uncover the "real truth" or "inside story" of events at the Branch Davidian's Mount Carmel property outside Waco.

Together these programs make bold claims about new discoveries or revelations previously unknown or undisclosed. However, as a scholar who has invested hundreds of hours researching this tragic confrontation over the last quarter century, I find the claims to be largely exaggerated, perhaps for commercial appeal or possibly to attract a new generation of viewers too young to remember this calamity. We now have a substantial body of scholarly research on Waco which offers considerable clarification on some of the still publicly contested issues and facts highlighted in these programs. ${ }^{2}$ As such, this body of scholarship provides a baseline for fact-checking some dubious claims.

\footnotetext{
${ }^{2}$ James D. Tabor and Eugene V. Gallagher, Why Waco? Cults and the Battle for Religious Freedom in America (Berkeley: University of California Press, 1995; Stuart A. Wright, Armageddon in Waco: Critical Perspectives on the Branch Davidian Conflict (Chicago: University of Chicago Press, 1995); James R. Lewis, From the Ashes: Making Sense of Waco (Lanham, MD: Rowman \& Littlefield, 1994); Jayne Seminaire Docherty, Learning Lessons from Waco: When Parties Bring their Gods to the Negotiation Table (Syracuse: Syracuse University Press, 2001); Kenneth G. C. Newport, The Branch Davidians of Waco (Oxford: Oxford University Press, 2006); Nancy T. Ammerman, "Waco, Federal Law Enforcement, and Scholars of Religion," pp. 282-296 in Stuart A.
} 


\section{Stuart A. Wright}

In the 2018 documentaries, notably the ones aired on CBS, ABC, the History Channel, the Smithsonian Channel, and to a lesser extent, HLN, there are a number of assertions by individuals that are not supported by the evidence, yet seem to be taken at face value by the filmmakers. To assess the validity of these assertions it would only require that the filmmakers do some digging into the published research. Instead, we see what appears to be a conscious effort to pursue the more salacious elements of the group's beliefs and practices in a distinctly tabloid-style of journalism. It is not disputed that Koresh took plural wives, some of them underage; to fulfill what he believed was a prophetic mission. While this and other controversial sectarian practices based on extraordinary religious claims are intriguing, they are secondary to the larger set of problems that define the conflict at Waco. I will return to the

Wright, Armageddon in Waco; Stuart A. Wright, "Anatomy of a Government Massacre: Abuses of Hostage-Barricade Protocols during the Waco Standoff." Terrorism and Political Violence 1999, 11 (2):39-68; John Hall, Philip D. Schuyler and Sylvaine Trinh, Apocalypse Observed (New York: Routledge, 2000; see chapter 2); Catherine Wessinger, How the Millennium Comes Violently (New York: Seven Bridges Press, 2000; see chapter 4); Eugene V. Gallagher, "Theology is Life and Death: David Koresh on Violence, Persecution, and the Millennium," pp.82-100 in Catherine Wessinger, ed., Millennialism, Persecution, and Violence (Syracuse: Syracuse University Press, 2000); James T. Richardson, "'Showtime' in Texas: Social Production of the Branch Davidian Trials," Nova Religio 2001, 5, 152-170; Jean Rosenfeld, "The Use of the Military at Waco: The Danforth Report in Context, Nova Religio 20015 (1):171-185; Jayne Seminaire Docherty, "Why Waco Has Not Gone Away: Critical Incidents and Cultural Trauma," Nova Religio 20015 (1):186-202; Stuart A. Wright, "Justice Denied: The Waco Civil Trial." Nova Religio 20015 (1): 143-51; John Wallis, Apocalyptic Trajectories: Millenarianism and Violence in the Contemporary World (Oxford: Peter Lang, 2004; see chapter 3); Stuart A. Wright, "A Critical Analysis of Evidentiary and Procedural Rulings in the Branch Davidian Civil Trial," pp.101-113 in Derek Davis (ed.), New Religious Movements and Religious Liberty in America (Waco: Baylor University Press, 2002); Stuart A. Wright, "Why Negotiations at Mt. Carmel Really Failed:

Disinformation, Dissension and Psychological Warfare," pp.42-56 in David Tabb Stewart (ed.), Waco: Ten Years After (Georgetown, TX: Southwestern University Fleming Lecture Series, 2003); Stuart A. Wright, "Explaining Militarization at Waco:

Construction and Convergence of a Warfare Narrative," pp.75-97 in James R. Lewis, ed., Controversial New Religions (New York: Oxford University Press, 2005); Stuart A. Wright, "Revisiting the Branch Davidian Mass Suicide Debate." Nova Religio 200913 (2): 4-24; Catherine Wessinger, "Deaths in the Fire at the Branch Davidian's Mount Carmel: Who Bears Responsibility? Nova Religio 200913 (2):25-60; Kenneth G. C. Newport, "A Baptism by Fire: The Branch Davidians and Apocalyptic Self-Destruction," Nova Religio 200913 (2):61-94; Matthew D. Wittmer, "Traces of the Mount Carmel Community: Documentation and Access," Nova Religio 200913 (2):95-112. [Note: This compilation of research is partial and represents only a portion of the complete body of scholarship on Waco]. 
argument shortly, but to finish my previous point, the focus of several documentaries is distinctively myopic.

The CBS 48 Hours episode, Secrets of Waco, for example, turns to critical ex-members to highlight what one individual called "mind control." The term "mind control" is a pseudo-scientific concept, found in science fiction literature but thoroughly debunked by social science research. ${ }^{3}$ The film producers make no effort to challenge the assertion. Indeed, it is woven into the plot and left to become a key theme in the framing of the story. The tone of sensationalism here is stark. One of the ex-members who appears on the program, Marc Breault, authored a turgid biographical account (Inside the Cult, 1993) shortly after the deadly assault. In the book, Breault reveals that he actively worked with Bureau of Alcohol, Tobacco, and Firearms (ATF) investigator Davy Aguilera as a self-proclaimed "cult buster" attempting to have Davidan leader David Koresh arrested. ${ }^{4}$ There are numerous problems with claims made by Breault that I found to be highly speculative or factually contested. Breault was the source for the false claim by ATF that the Davidians were manufacturing illegal drugs. ${ }^{5}$ They were not, and Breault certainly knew this. Breault also gave embellished descriptions of life at Mt. Carmel which likely contributed to the overreaction of the ATF's response in the planning of the raid. ${ }^{6}$ I interviewed Breault's former roommate at Mt. Carmel, Wally Kennett. Kennett vehemently rejects several accounts of alleged incidents in Breault's book in which heKennett--was present. I have written about this in some depth elsewhere, but Kennett said that Breault was given to exaggeration and "had a tendency to tell tall tales." In an unsolicited comment, Kennett stated,

\footnotetext{
${ }^{3}$ Dick Anthony, "Religious Movements and Brainwashing Litigation," pp.295-344 in Thomas Robbins and Dick Anthony, eds., In Gods We Trust (New Brunswick, NJ: Transaction, 1990); Dick Anthony, "Pseudoscience and Minority Religion: An Evaluation of the Brainwashing Theories of Jean-Marie Abgrall." Social Justice Research 1999 12:421-456; Dick Anthony and Thomas Robbins, "Law, Social Science, and the Brainwashing Exception to the First Amendment." Behavioral Sciences and the Law 1992 10:5-30; James T. Richardson, "Brainwashing' claims and minority religions outside the United States: Cultural diffusion of a questionable legal concept in the legal arena.

Brigham Young University Law Review, 1996 873-904; James T. Richardson, "Cult/brainwashing cases and the freedom of religion." Journal of Church and State, 1991 33: 55-74.

${ }^{4}$ Marc Breault and Martin King, Inside the Cult (New York: Signet, 1993) p.208.

${ }^{5}$ See Investigation into the Activities of Federal Law Enforcement Agencies toward the Branch Davidians, Thirteenth Report by the Committee on Government Reform and Oversight and the Committee on the Judiciary, August 2, 1996, pp. 3, 45-46; Wright, "Explaining Militarization at Waco," p.94.

${ }^{6}$ Wright, "Explaining Militarization at Waco," pp.87-91.
} 


\section{Stuart A. Wright}

"The guy also claimed he had seen me level a Ruger mini-fourteen at the paperboy's head at four o'clock in the morning when it was pitch dark." He dismissed the claim and said, "This guy (Breault) is full of crap."7 Some other things Breault was reported to have seen in the dark at night have been challenged because Breault is legally blind. ${ }^{8}$ The Davidians I interviewed were quick to point out that Mr. Breault could not read without holding printed materials up to his face and that he could not recognize people or objects even from a short distance. ${ }^{9}$

There are other problems with the CBS 48 Hours segment, Secrets of Waco. One focus of the program is the interview with the UPS driver who first reported suspicious shipments to Mount Carmel. Larry Galbreath recalled how he dropped a package and "grenades" spilled out while making a delivery. Mr. Galbreath's account is somewhat misleading. The package contained empty grenade shells. The Davidians later claimed that the grenade shells were mounted on plaques and sold at gun shows. At the 1995 Congressional hearing, the attorney for sect member Steve Schneider, Jack Zimmerman, held up one of the plaques to show the committee. The government has challenged this account claiming that the group was making live grenades, but given the problems with the preservation of the crime scene and the mishandling of evidence, ${ }^{10}$ this assertion remains disputed.

In another part of the CBS program, Dallas Morning News reporter Lee Hancock states that the Branch Davidians "murdered" ATF agents in the initial raid. This statement has no merit. The jury in the criminal trial of eleven Branch Davidians in San Antonio in 1994 acquitted the sect members of murder and conspiracy to murder charges. The "murder" claim surfaces in other documentaries as well, boldly declared by federal agents without regard for the actual verdicts in the criminal trial.

Finally, to the dismay of this observer, no scholars who have conducted extensive research on the Branch Davidian case are interviewed in the documentary. There are a dozen or more scholars on Waco who are still active in the academy. There is no mention of any of these scholars' work or the comprehensive research literature published on the conflict.

Like the CBS documentary, the ABC 20/20 episode, Truth and Lies: Waco, fails to include even a single scholar on Waco. Instead, it

\footnotetext{
${ }^{7}$ Wright, "Explaining Militarization at Waco," p.89.

${ }^{8}$ Wright, "Explaining Militarization at Waco," p.89.

${ }^{9}$ Wright, "Explaining Militarization at Waco," p.89.

${ }^{10}$ Stuart A. Wright, "Field Notes from Waco: Isabel Andrade et al v. U.S." Nova Religio 4 (2): $351-56$.
} 
prominently features an investigative reporter from the syndicated news magazine TV program, A Current Affair, Mary Garafalo. By my count, Ms. Garafalo appears on the documentary to comment more than thirty times. It's not clear what qualifies this reporter to receive so much face time.

ABC 20/20 Truth and Lies also features a mix of ex-members and survivors who appear in the program-David Bunds, Robin Bunds, Kiri Jewell, Dana Okimoto, Clive Doyle, David Thibodeau, and Sheila Martin. There is a better balance to the conflicted emotions and feelings disclosed in these interviews. Some of the comments by ex-members David and Robin Bunds highlight the gray areas where lived experience in the community reveals more nuance and context. These interviews actually reflect the ambivalence of attitudes found in studies of exmembers. ${ }^{11}$ Nonetheless, the program seens intent on exploiting the more scandalous practices of the group. Consequently, it ignores the larger and more disturbing issues in the tragic events at Mount Carmel. Was the federal raid even necessary? Did the ATF have other, less dangerous options to serve the arrest warrant to Koresh? Could the standoff have been resolved peacefully? Was the FBI's tank and CS gas assault on April 19 the best course of action?

Instead of examining these questions, the $\mathrm{ABC} 20 / 20$ program presents Byron Sage, a retired FBI agent who was a negotiator during the Mount Carmel siege, and who appears incapable of admitting to the numerous miscalculations and errors made by the FBI. He places all the blame for the tragedy on Koresh and the Branch Davidians. Sage's account is doctrinaire and disingenuous as is made clear by the counternarrative of his colleague, Gary Noesner, who was negotiation coordinator at Waco for the first half of the siege, and later promoted to Chief of the FBI's Crisis Negotiation Unit. Though Noesner is seen only briefly "Truth and Lies," he explicitly contradicts Sage. Noesner is a more prominent figure in a few of the other documentaries discussed here and in the Paramount Network's Waco miniseries. Noesner delineates the problems in communication within the HRT, and with the on-site commander Jeffrey Jamar. With the support from officials in the

\footnotetext{
${ }^{11}$ Stuart A. Wright, "Post-Involvement Attitudes of Voluntary Defectors from Controversial New Religious Movements." Journal for the Scientific Study of Religion 1984, 23 (2): 172-182; Stuart A. Wright, "Leaving New Religious Movements: Issues, Theory and Research," pp. 143-165 in David G. Bromley, ed., Falling From the Faith: The Causes and Consequences of Religious Apostasy (Beverly Hills: Sage, 1988); Stuart A. Wright, "Reconceptualizing Cult Coercion and Withdrawal: A Comparative Analysis of Divorce and Apostasy." Social Forces 1991, 70 (1): 125-145.
} 


\section{Stuart A. Wright}

command center in the FBI's Hoover Building in Washington, D.C., ${ }^{12}$ Jamar facilitated the HRT's rush to implement show-of-force operations while ignoring the advice of negotiators who pleaded for patience and a peaceful end to the standoff.

Information has leaked out slowly over the years about problems with communication that existed within the FBI during the siege. Noesner's recent public comments, as well as his book, Stalling for Time: My Life as an FBI Hostage Negotiator (2010), have confirmed suspicions that some of us had all along. Indeed, I attempted to make this argument nearly twenty years ago. I was able to obtain some training materials outlining protocols used by the FBI in how to conduct hostage-barricade incidents. My analysis of these protocols uncovered sixteen violations by the HRT during the Waco standoff. ${ }^{13}$ It was evident to me back then that the HRT's focus on militarized tactical solutions undermined good-faith negotiations with the Branch Davidians which contributed to a premature termination of the standoff and culminated in the CS gas assault and needless deaths of seventy-six men, women, and children.

The format of the History Channel documentary, Days that Shaped America: The Waco Siege, departs from the others in that it is essentially the story of two former ATF agents, Bill Buford and Eric Evans. It dramatically depicts how the ATF raid on the Branch Davidians altered their personal lives. (Needless to say, no Waco scholars are interviewed and the filmmakers appear to be unaware of the research literature). A human interest piece, The Waco Siege allows the two former agents to construct their accounts as victims. Viewers can appreciate the sacrifice both of these men made as law enforcement agents. But Buford, who sustained serious and life-long injuries in the raid, does not take any responsibility for critical failures in the planning of the raid. This is a problem - or deliberate oversight—since the documentary fails to point out that Buford helped plan the raid. ${ }^{14}$ Here is what the Congressional Committee on Government Reform and Oversight and the Committee on the Judiciary concluded in their joint report with regard to the ATF raid:

The ATF's raid plan for February 28 was significantly flawed. The plan was poorly conceived, utilized a high risk tactical approach when other tactics could have been successfully used, was drafted

\footnotetext{
12 Wessinger, "The FBI's 'Cult War' against the Branch Davidians."

${ }^{13}$ Wright, "Anatomy of a Government Massacre," 1999.

${ }^{14}$ Ian Simpson, "Ex-ATF Agents Recall Storm of Gunfire in Deadly 1993 Waco Raid," Reuters February 8, 2013, https://www.reuters.com/article/us-usa-waco-atfidUSBRE9170JC2013028.
} 
and commanded by ATF agents who were less qualified than other available agents, and used agents who were not significantly trained for the operation. ${ }^{15}$

The film's producers seem to miss the cruel irony of Buford's victimization. The entire raid was unnecessary and hence, his injuries are in no small part a result of his own actions in the planning of the failed raid. This point is made forcefully in another section of the Congressional report which notes that the warrant for Koresh could have been served outside the Mt. Carmel property, thus avoiding the dangerous high-risk raid altogether.

David Koresh could have been arrested outside the Davidian compound. The ATF chose not to arrest Koresh outside the Davidian residence and instead were determined to use a dynamic entry approach. In making this decision ATF agents exercised extremely poor judgment, made erroneous assumptions, and ignored the foreseeable perils of their course of action. ${ }^{16}$

Former HRT member Ken Vincent is also interviewed in the History Channel documentary. He states that there is "no playbook" for this kind of incident. I find this statement to be an artful dissembling of the facts. The FBI established its hostage negotiation training program at the FBI Academy in Quantico in 1973, following the tragic deaths of Israeli hostages at the 1972 Munich Summer Olympics. The Special Operations and Research Unit (SOARU) of the Academy focused on coordinating efforts by behavioral scientists and law enforcement personnel to develop a rigorous curriculum and training in crisis negotiations. ${ }^{17}$ Crisis negotiation training combines the principles and applications of criminal justice, sociology, psychology, communications, and other disciplines into a single conceptual framework. The problem at Waco wasn't that the FBI didn't have a reliable set of guidelines and protocols in place ("playbook"), the problem was that they tossed the book aside; their actions didn't comply with their own guidelines. ${ }^{18}$

\footnotetext{
${ }^{15}$ Investigation into the Activities of Federal Law Enforcement, p.3.

${ }^{16}$ Investigation into the Activities of Federal Law Enforcement, p.3.

${ }^{17}$ SOARU is now called the Crisis Management Unit and is part of the Critical Incident Response Group (CIRG). Thomas Strentz, Psychological Aspects of Crisis Management, Third edition, Routledge, 2018.

${ }^{18}$ Wright, "Anatomy of a Government Massacre," 1999
} 


\section{Stuart A. Wright}

The Smithsonian documentary, Waco: The Longest Siege, is disappointing for some of the same reasons mentioned above. It is a morality tale peppered with heavy doses of cult shaming by the narrator, federal agents, ex-members Marc Breault and Elizabeth Baranyi, and others. To compound this problem, there are a number of factual errors or misleading statements in the documentary. At one point in the film, the narrator notes that Koresh married his wife Rachel when she was fourteen and states that the legal age of marriage in Texas was seventeen, implying that there was something nefarious about the marriage. In fact, a woman could be married as young as fourteen with parental consent in the state of Texas up until 2006. Rachel's parents, lifelong Davidians Perry and Marybell Jones, gave their consent for the marriage. At another point in the documentary, the narrator refers to a video made by the Branch Davidians during the siege and says Koresh tried "to exploit it with a calculated PR offensive." I have a personal copy of this twohour video and have watched it a dozen times over the years. No objective observer would draw this conclusion from the video. The video camera was sent into Mount Carmel by the FBI to garner intelligence about the barricaded sect members. They were told to talk about themselves on the video. The FBI later refused to release it to the public for fear that it would humanize the Davidians, evidently countering the sustained efforts to demonize them in press briefings. ${ }^{19}$

On at least two occasions, the narrator refers to the Book of Revelations (sic), revealing a pedestrian knowledge of the Bible. But as in the ABC, CBS, and History Channel documentaries, the Smithsonian documentary fails to interview any scholars on Waco. Toward the end of the film, the narrator intones that Koresh's message was getting darker and more violent in the months before the federal raid. This statement is followed by a photo of Koresh holding a rifle. The date of the photo is not mentioned but it was taken six years before the raid during a 1987 trial at which Koresh and others faced charges involving a confrontation with George Roden (the real madman of Waco). The jury declined to convict Koresh on any of the charges and the photo does not support the claim made in the film.

The HLN documentary (Waco: How it Really Happened with Hill Harper) edges toward a slightly better balance of events surrounding the federal siege and standoff. We see a greater proportion of interviews with Davidian survivors and sympathetic family members as well as insightful commentary by Waco scholars Catherine Wessinger and J. Phillip

\footnotetext{
${ }^{19}$ Wright, "Anatomy of a Government Massacre," pp.47-8.
} 
Arnold. Texas journalist and former Nieman Fellow in Journalism, Dick Reavis, was also interviewed. Reavis authored The Ashes of Waco (1995), and provides critical perspective on the ATF investigation leading up to the raid. Retired FBI negotiator Gary Noesner, who was negotiation coordinator until he was removed by the onsite commander, explains to listeners how the aggressive actions of the HRT undermined negotiations. ${ }^{20}$ Koresh's attorney, Dick DeGuerin, describes how Koresh told him on April 14 he would leave the residence after he had written down his interpretation of the Seven Seals. DeGuerin reports that he was told by the FBI that "we have all the time it takes." The next day, however, the HRT launched its deadly tank and CS gas assault on the barricaded sect members.

While not hegemonic, the law enforcement narrative is still present in the HLN documentary. Interviews with former ATF agents Bill Buford, Roland Ballesteros, and Chuck Hustmyre are included. Hustmyre repeats the fraudulent claim that the Davidians "murdered" ATF agents. Retired FBI Special Agent in Charge Jeffrey Jamar appears on camera to falsely assert that the Bureau had "absolute evidence that Koresh never even started the Seven Seals." In fact, Koresh had finished his commentary on the First Seal and was working on the Second Seal when the tank and CS gas assault was launched. The document containing the First Seal commentary was brought out of the fire by Branch Davidian survivor Ruth Riddle on a computer disk. ${ }^{21}$

The A\&E documentary (Waco: Madman or Messiah?), despite the garish title, is also a fairer treatment of the Waco conflict than the CBS, $\mathrm{ABC}$, History Channel, or Smithsonian Channel programs. The coverage is less myopic and less dismissive of the Branch Davidian community. The interviews with survivor Kathy Jones and her daughter and Kathy Schroeder and her daughter humanize the Davidians. Their comments and insights give viewers a more empathetic look into the families and shared relations of the community. I was taken aback at the interview with David Koresh's aunt, Sharon Kidd, who described the abuse young Vernon Howell experienced at the hands of his stepfather. Vernon was kicked out of the house and went to live with his aunt in his early teens. Sharon was informed by young Vernon that one day the government would kill him. She told the interviewer, "I've never forgotten that." Survivors Graeme Craddock and Kathy Jones both said that Koresh

\footnotetext{
${ }^{20}$ See also Gary Noesner, Stalling for Time: My Life as an FBI Hostage Negotiator (New York: Random House, 2010), 100, 110, 112, 117, 119-20, 123, 124, 125-27.

${ }^{21}$ Koresh's incomplete Seven Seals commentary is published as an appendix in Tabor and Gallagher, Why Waco? 191-203.
} 


\section{Stuart A. Wright}

prophesied a government raid and said they would "kill us." The federal siege and standoff, carried out in such spectacular fashion, certainly adds to the mystique surrounding Koresh.

The A\&E documentary also includes interviews with scholars James D. Tabor and J. Phil Arnold, who were key players in the unfolding drama of how Koresh might interpret the government's actions at Mount Carmel in light of biblical prophecies. Tabor and Arnold ultimately persuaded Koresh that the passages in the Book of Revelation regarding the Fifth Seal could be interpreted differently so as not to point to an evitable "final battle" in which Koresh and other Branch Davidians would be killed. So what do we learn from these scholars? We learn that Arnold initially approached FBI agent Bob Ricks, who was the FBI's spokesperson during the press briefings, and offered to help interpret Koresh's theology for the agents, but was rebuffed. Undaunted, Tabor and Arnold then used a local radio broadcast to communicate their message to Koresh. On April 14, the day after Passover, the FBI agents in Waco received a letter from Koresh that conveyed his intent to come out after completing his interpretation of the Seven Seals. These interviews with Tabor and Arnold give viewers critical pieces of information about the standoff--namely, that it could have ended differently had the FBI shown more patience and been willing to work with knowledgeable third party intermediaries in the negotiations.

The A\&E documentary is not entirely sympathetic to the Branch Davidians. Marc Breault is interviewed to alert viewers about the dangers of cult leaders like Koresh ("he had to make the apocalypse happen"). Byron Sage appears again to repeat his version of events. He adds the observation that "none of the Davidian survivors brought out a child with them." This reprehensible statement ignores the fact that after six hours of exposure to CS gas many of the men, women and children had already suffocated or were in a comatose state. ${ }^{22}$ Furthermore, the people were scattered throughout different locations in the building. During the April 19 assault, a Combat Engineering Vehicle driven by a member of the FBI's HRT drove into the residence and gassed the women (including two who were pregnant) and small children sheltering in a concrete room from 11:31 a.m. to 11:55 a.m. The fire started at 12:07 p.m. ${ }^{23}$ and quickly consumed the building.

In Waco: Madman or Messiah? retired ATF agent Robert Rodriguez tells the viewing audience that the Davidians "were there to die." One of

\footnotetext{
${ }^{22}$ Wright, "Revisiting the Branch Davidian Mass Suicide Debate," pp.8-11.

${ }^{23}$ Wessinger, "Deaths in the Fire at the Branch Davidians' Mount Carmel," 40-42.
} 
the most revealing interviews was conducted with retired HRT operator Jim McGee, who admits that "I wanted to do an assault. I wanted him (Koresh) to pay for killing those four ATF agents. ...I fired about 93 gas rounds (ferret rounds)" into the building. This statement can be coupled with a prescient comment in the Smithsonian Channel documentary by Davidian survivor Clive Doyle who, after realizing the size of the ATF raid force and the number of wounded agents, told the interviewer, "The feeling I had was, oh no, they are going to want revenge."

The Paramount Network docudrama, Waco, created by brothers Drew Dowdle and John Erick Dowdle, is an intriguing effort to mine the internal relationships and dynamics of both the Davidians and the FBI agents on site in Waco. The six-part miniseries is based on two booksan autobiography written by Branch Davidian survivor David Thibodeau with Leon Whiteson, A Place Called Waco: A Survivor's Story (1999), and Gary Noesner's book, Stalling for Time-in addition toother research. The six episodes give us a more nuanced portrait of Koresh and the Branch Davidians, largely through the eyes of David Thibodeau. Key members Judy and Steve Schneider, Michelle Jones, Rachel Howell/Koresh, Thibodeau and others are fleshed out, humanized, given sympathetic personality and character treatments. It is a major triumph that the (fictionalized) lives of the people inside Mount Carmel are not simply dismissed as disembodied cultists. The portrayal of Koresh by the actor Taylor Kitsch is remarkable, providing insight into his charismatic appeal and inspirational leadership, despite the controversial doctrines he espoused. The gut-wrenching struggles of members to accept these doctrines are on full display. There are visceral tensions in the group; the Davidians are not simply programmed, brainwashed robots.

The dramatization of Gary Noesner's role as FBI negotiation coordinator on the scene will be a revelation to some. In the episodes of the miniseries, Noesner complains to supervisors early on about the militarization of the FBI through significant funding of the HRT. By the time of the Ruby Ridge standoff with Randy Weaver, six months before Waco, he is already wrestling with the strained relations between negotiators and the HRT commander. The increased frustration and acrimony is played out to its fullest during the 51 day standoff at Waco. In a separate recorded video on the Paramount Network Waco website featuring interviews with figures dramatized in the miniseries, the real Gary Noesner states:

As I learned, there was a great deal of pressure from the tactical side to have me replaced because I was clearly an impediment to their 


\section{Stuart A. Wright}

sense that ratcheting up their tactical maneuvers would be a way to resolve this. ...We did eventually get 35 people out. But after that some very provocative actions were taken by the tactical team and Koresh went ballistic. He said "that's it; no one else is coming out." 24

Taken as a whole, the quality of the 2018 documentaries on Waco is very uneven. The CBS, ABC, History Channel and Smithsonian Channel programs are awash in tabloid-style journalism and rely entirely too much on a selective law enforcement narrative. By "selective" I mean that the narrative or frame is dictated predominantly by the defenders of federal actions at Waco. While a dissenting voice like Noesner's is acknowledged, his is a minority view. This narrative serves as a gatekeeping function to preserve the impression that actions of the ATF and FBI at Waco were necessary and unavoidable. Nothing could be further from the truth.

The HLN and A\&E documentaries make a concerted effort to give a more balanced treatment on Waco. They do not ignore the criticism and controversy surrounding Koresh and the Branch Davidians, but neither do these programs descend into obsessive scandalizing. By widening the scope of their investigations to Waco scholars, Davidian survivors, family and kin, Koresh's attorney, and other parties not overtly antagonistic to the sect, we get a broader perspective.

In contrast, the Dowdle brothers' dramatic interpretation of events in their six-part miniseries aired on the Paramount Network is grounded in the firsthand views of primary actors. This provides alternative viewpoints that challenge the conventional wisdom on Waco. It is somewhat ironic that a fictional representation of events comes closer to the truth than documentaries, which are supposed to be fact-based.

My strongest criticism of the Waco programs is reserved for the misguided focus of the first four documentaries discussed here. Koresh certainly could have been charged with sexual assault of minors. Some observers express outrage at the sexual practices of Koresh taking multiple women as spiritual wives (though it does not involve any criminal acts). While the documentaries spend an inordinate amount of time on the salacious sexual aspects of the community, the ATF raid was predicated on firearms violations. The ATF has no jurisdiction in matters of child sexual abuse. This was a raid conducted to find guns. Yet very

\footnotetext{
24 "Revelations of Waco: How Not to Negotiate with Believers," Paramount Network, 21 February 2018, http://www.paramountnetwork.com/video-clips/qvaigm/wacorevelations-of-waco-how-not-to-negotiate-with-believers.
} 
little time was allotted in these documentaries to analyze the firearms charges, the sources of evidence to launch a massive paramilitary raid, or the options available to the ATF for less dangerous or less lethal enforcement actions.

While many safer options were available to the ATF, I will cite just one. None of the programs mention the fact that months before the raid, ATF investigator Davy Aguilera was offered a chance to visit Mount Carmel and inspect the firearms. During a compliance inspection of a gun dealer who sold firearms to Koresh, agent Aguilera was given a personal invitation by Koresh himself to inspect his weapons. Inexplicably, refused the invitation. The Congressional report later condemned the ATF for this decision, saying "The agent's decline of the Koresh offer was a serious mistake." 25 This is a spectacular understatement given the deadly outcome of the raid and subsequent siege and final assault conducted by the FBI standoff. The failure of these documentaries to drill down further, invest the necessary time and effort to uncover the various government miscalculations and misfeasance at Waco is itself another chapter in this historic tragedy. The ATF ignored a number of options and seemed intent on launching a dangerous, high-risk raid. ${ }^{26}$ The 1993 Treasury Department report made this same observation when it described the ATF planning of the raid as "steps taken along what seemed at the time to be a preordained road."27

It is essential that scholars subject this new round of mass media coverage of Waco to careful analysis to preserve the accuracy of the historical record. The passion and fervor of various parties with regard to the events at Waco make for an easily distorted image or public misunderstanding. We cannot abandon this cautionary tale of government overreach to the revisionism of culpable state actors or the foibles of drive-by journalism.

\footnotetext{
${ }^{25}$ Investigation into the Activities of Federal Law Enforcement, p.10.

${ }^{26}$ Investigation into the Activities of Federal Law Enforcement, 14-15.

${ }^{27}$ Report of the Department of Treasury on the Bureau of Alcohol, Tobacco, and

Firearms Investigation of Vernon Wayne Howell, Also Known as David Koresh. U.S.

Department of Treasury, 1993, p.174.
} 